\title{
The role of macrozoobenthos and periphyton in bioindication of water resources quality in Uzbekistan
}

\author{
Abdulla Kurbanov ${ }^{1}$, Natalie Titova ${ }^{1}$, Zuri Mustaphaeva ${ }^{2}$, Nargis Atabaeva ${ }^{3}$ \\ ${ }^{1}$ Scientific research institute of fishery, adviser of rural residents of Kosh-Yagach, Yangiyul district, \\ Tashkent region, Uzbekistan \\ ${ }^{2}$ Institute of zoology of Academy of sciences of the Republic of Uzbekistan, Bogishamol street 232-b, \\ Tashkent, Uzbekistan \\ ${ }^{3}$ National University of Uzbekistan named after Mirzo Ulugbek, Faculty of Ecology, University str.-4, \\ Almazar district, Tashkent, Uzbekistan
}

\begin{abstract}
The material was collected during the open water period from March to the end of November 2019. In the period of our research in the basin of the Chirchik river (Boshkizylsay river, Ugam river (pre-settlement site), Chirchik river) were discovered several types of zoobenthos and periphyton. The monitoring was carried out on 8 stations, in total of 64 quantitative samples of macrozoobenthos and periphyton were taken. Anthropogenic pollution causes changes in the composition and structure of aquatic communities, expressed in the change of dominant complexes of organisms, the simplification of the ecological structure, the appearance of highly saprobic species in the composition of the dominants.
\end{abstract}

\section{Introduction}

Freshwater is a necessary resource for all life on the planet and habitat for living organisms. The rationing of pollution of water bodies is intended to preserve the high quality of water for the livelihood of people, to maintain a stable functioning of aquatic and terrestrial ecosystems. What kind of water can we consider favorable?

The appropriate question is what will these deviations mean for living systems? In turn, biological specialists suggest taking into account indicators of the disturbance of the state of individuals of populations and communities. It is not clear under what conditions (under what indicators of water quality) did the recorded changes in biological systems occur?

In turn, biological specialists suggest taking into account indicators of the disturbance of the state of individuals, populations and communities. It is not clear under what conditions (under what indicators of water quality) the recorded changes in biological systems occurred. According to GOST, water quality is understood as "a set of physical, chemical and biological properties of water with regard to the requirements of specific water users". (GOST 27065-86, water quality, 1987). Since water is a vital resource for all living organisms, including humans and habitat for aquatic organisms, its quality should be assessed only in relation to living systems. The properties of natural waters are formed as a result of complex processes in the catchment area and reservoir: 
- Physico-chemical: chemical weathering of elements, their interaction, filtration, migration, adsorption, desorption of elements and atmospheric precipitation.

- Biological: biochemical, microbiological, biofiltration.

The last decades are characterized by a sharp increase in the anthropogenic load on reservoirs and watercourses. There is a progressive deterioration in the quality of the aquatic environment, which is a threat to the ecological, food and national security of the country. With the existing pollution of water bodies, the assessment of only the amount of water is insufficient, since it does not ensure the adoption of correct, comprehensively informed decisions. In modern conditions, the most important element in the use of water resources is water quality accounting. Specific technogenic factors and their influence on the formation of hydrological and hydrochemical regimes that determine the conditions for the development of aquatic biota are characteristic of any basin. The purity of the water of a natural reservoir can be judged by the species diversity and abundance of the animal population. [1] Currently, various indicator organisms of benthic (benthic) communities that have long life cycles, lead a sedentary lifestyle and are therefore good indicators of water quality are successfully used to assess water quality. [4, p.29] Usually for bio-diagnostics of water bodies, macrozoobenthos is used, the relatively large dimensions of which (from $2 \mathrm{~mm}$ and higher) facilitate the task of detecting and recognizing these organisms [6, p.22].

High demands on the conditions of existence of a number of aquatic invertebrate species, confinement to certain substrates, and relative low mobility allow using zoobenthos to record the anthropogenic impact on aquatic ecosystems. The presence of toxic chemicals in the surface waters of the land most often causes the death of aquatic organisms, the disappearance not only of individual widows, but also of large taxa - inhabitants of pure waters and their replacement by euribiont organisms. The toxic effect of pollutants on hydrobiota is one of the main causes of the negative effects of anthropogenic pollution of natural waters. toxicity is known to be one of the characteristics of water quality. [1, p. 3]

\section{Material and methods}

Periphyton is one of the important biological components of aquatic ecosystems and is a collection of various organisms (animals and algae) that live on a variety of underwater (living or dead) substrates, raised above the bottom, regardless of their origin (Fig. 1).

\section{PERIPHYTON I}

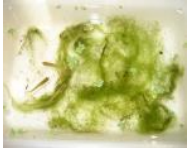

$\mathrm{a}$

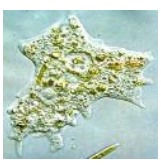

a

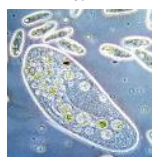

e

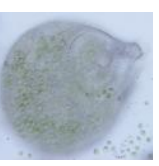

b

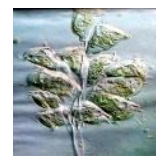

f
II

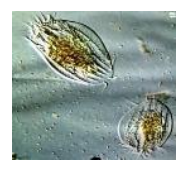

c

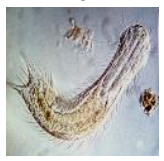

g

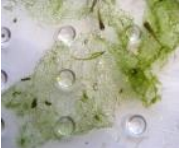

b

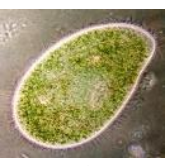

d

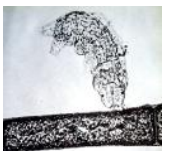

$\mathrm{h}$

Fig. 1- Representatives of the periphyton community

I- producers: a- Nitzschia, Lemna minor, Azolla Carolina, fish seeds; b-Hydrodiction reticulatum 
Lagerh.; II -consumers: a - Amoeba diffluens; $\mathrm{b}$ - Chilodonella sp.; c - Euplotes patella (O.F.M.) Ehr.; d - Paramecium bursaria Ehr.; e - P.caudatum Ehr.; f - Carchesium polypinum Linne; gChaetonotus sp.; $\mathrm{h}$ - Hypsibius dujardini (Doyere).

Functionally, zoobenthos is an important part of the heterotrophic component of ecosystems, and the animal organisms that represent it belong to consumers. The species composition and quantitative development of benthal organisms well characterize the degree of soil and bottom water pollution. [6, p. 48] The phytali population more characterizes the quality of the water mass in the water body. On fig. 2 only a small part of the inhabitants of the river bottom of the Tashkent region is shown.
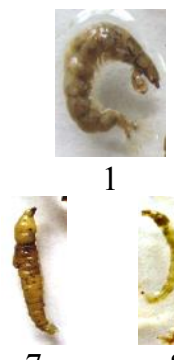

7

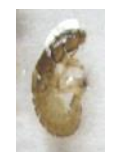

2

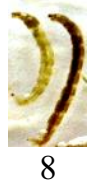

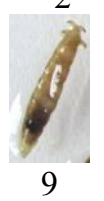

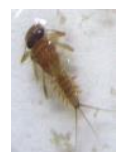

3

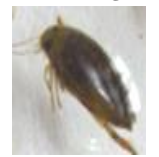

10

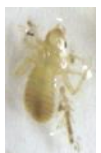

4

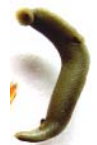

11

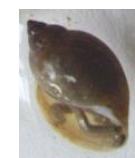

12

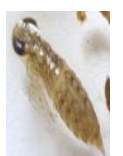

5

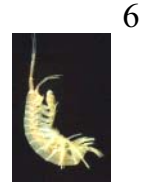

13

Fig.2 Complex of organisms of river zoobenthos:

Larvae of caddisflies of genera - Hydropsyche (1), Cheumatopsyche (2); mayflies larvae of Heptagenidae family (3), Dragonfly of Libellulidae family $(4,5)$; larvae of Diptera - families Chironomidae (6-8); Tabanidae (9); bugs of Gyrinidae family (10); Hirudinea of Herpobdellidae family (11); Mollusca of Physidae family (12); Gammaridae family (Gammarus lacustris Sars. 13).

The material was collected during the open water period from March to the end of November 2019. The monitoring was carried out on 8 stations, in total of 64 quantitative samples of macrozoobenthos and periphyton were taken. [7, p. 6] Sampling and processing of macrozoobenthos samples was carried out in accordance with the methods and recommendations. [3, p. 86, 6 p. 21] Dominants were determined by frequency of occurrence. The structure of benthic communities was estimated by the number of taxons (S), ShannonWeaver species diversity index (N, bits / spec.), Abundance $\left(\mathrm{spec} . / \mathrm{m}^{2}\right)$, biomass $\left(\mathrm{g} / \mathrm{m}^{2}\right)$. Water quality was characterized by the following metrics: for zoobenthos, a modified biotic index (MBI), adapted to the conditions of Central Asia, the Woodiwiss biotic index. [6, p. 6] Figure 3 shows the sampling points for zoobenthos and periphyton.

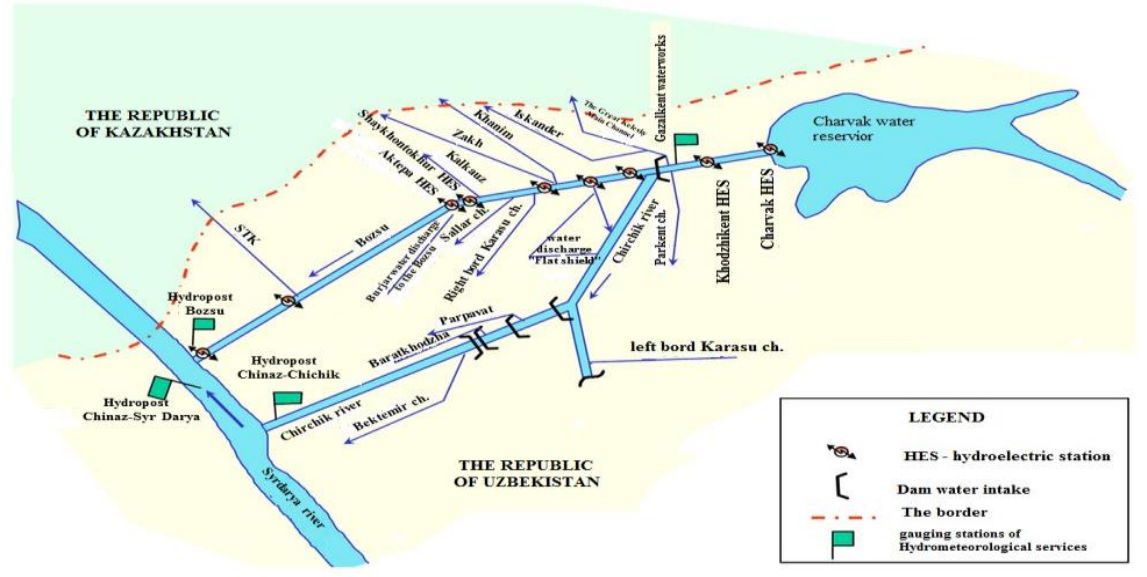

Fig. 3. The map of research area 
In 1981-year for macrozoobenthos organisms G.P. Bulgakov the specialist of Uzhydromet introduced relative abundance points similar to the frequency of occurrence on the gas scale used in calculating the index of saprobity using the Pantle and Buck method for periphyton, zoo and phytoplankton. For convenience, the characteristics of ecological invariant states of biocenoses in the objects under study are encoded in the form of letter indices: $\mathrm{AB}(\mathrm{F})$ is a background ecological state in which biocenoses are in a state of metabolic and ecological progress and are represented by a complex of species reflecting the natural (undisturbed) gene pool of the region; $A B$ is a satisfactory ecological condition characterized by metabolic and ecological progress by a biocenosis; $\mathrm{AB}-\mathrm{Ab}$ is a transitional ecological state associated with a noticeable change in the taxonomic and functional structure of biocenoses; $\mathrm{Ab}$ - unsatisfactory ecological condition, pronounced degradation of the ecological structure of the initial biocenoses; $a b$ - absolutely unacceptable ecological condition, complete degradation of biocenoses. [6, p. 37]

\section{Results and Discussions}

In the period of our research from the beginning of March 2019 to the end of November 2019 in the basin of the Chirchik river (Boshkizylsay river, Ugam river (pre-settlement site), Chirchik river) were discovered the following types of zoobenthos and periphyton.

The Boshkyzylsay river flows through the territory of the Chatkal reserve, it is a typical mountain stream with a large amplitude of fluctuations of water flow during the year. The range of observations is confined to the mountain forest belt. Intra-annual cyclic changes in the structure of periphyton Boshkyzylsay river on the regime point above the GMF did not go beyond the limits established in the previous year, and long-term observations.

Thus, in the periphyton biocenoses, X-, X-o-, o-saprobic cryophilic species of Achnanthes lanceolata and its variations, Ach. linearis, Ach. microcephala, Cymbella aegualis, C. cymbiformis, C. helvetica, Diatoma hiemale and its variation, Didymosphenia geminata, Fragilaria bicapitata, Gomphonema intricatum v. pumilum, Synedra Goulardii and its variation, $S$. amphicephala. In the spring-summer period in the periphyton, the development of the North-Alpine diatoms Ceratoneis arcus and its variation, Cymbella Stuxbergii, Fragilaria intermedia, and the golden alga Hydrurus foetidus were noted. At the same time, during the low-flown summer-autumn period (the height of the "biological summer"), brook, spring, mountain-piedmont and lowland ob- and b-mesosaprobic species with a wide ecological valence, as well as forms that biotopes with plant detritus accumulated, developed significantly. - Cymbella helvetica v. curta, C. affinis, C. amphicephala, C. delicatula v. sibirica, C. sinuata, C. lanceolata, C. microcephala, C. ventricosa, C. turgida, Achnanthes minutissima and its variation, Ach. affinis, Cocconeis pediculus, C. placentula and its variation, Fragilaria bicapitata, Melosira varians, Denticula tenue, Gomphonema olivaceum, G. intricatum v. pumilum, G.constrictum, Rhopalodia gibba, representatives of the genera Cyclotella, Amphora, Diatoma, Fragilaria, Navicula, Nitzschia, Synedra; bluecollar algae, algae from the genera Microcystis, Merismopedia, Gleocapsa, petropha, Anabaena, chamaesiphon, Oscillatoria, Lyngbya, Phormidium, Calothrix and etc.

The state of periphyton biocenoses testifies to the high quality of the water of the Boshkyzylsay river and its tributaries, and is characterized by high biotopic and biocenotic diversity, which is a consequence of the diversity of life conditions not disturbed.

Bottom communities are characterized by a fairly high and constant abundance and species diversity throughout the year. As part of zoobenthos, there are mountainous X-o-, osaprobic species of spring clans of the genera Mesoperlina, Athinehmura, Filchneria, mayflies - Iron montanus, Iron sinespinosus, Rshithrogena stackelbergi, Ephemerella submontana, Ecdyonurus rubrofasciatus, Baetis rhodshyshyshishish, an Rellatherathani submontana, Ecdyonurus rubrofasciatus var. caucasicus, Baetis (Acentrella) latus, 
caddisflies Hydropsyche ornatula, Rhyacophila obscura, Diptera Atherix, Blepharocera, water mites Protzia exima, Lebertia lineata, Atractides ellipticus, Megapus sp., piedmont, foramen (Nigrobaetis) muticus, Baeis stipposus, caddisflies Cheumatopsyche lepida, beetles of the genus Helmis. In the summer-autumn period, which is characterized by an increased level of trophicity and warming of the water mass, b-a-, a-mesosaprobic species of hallows Baetis transiliensis, Caenis macrura, caddisflies Hydropsyche gracilis, ticks, Sperchon plumifer, Hygrobates calliger, chironomid Rheocricotopus fuscipes, also develop. The values of IP - 1.16-1.53, BPI - 7-10 and MBI - 7-9 points, the quality of water varies from class I to class II; ecological condition - AB (F). [7, p.25]

Ugam river: the observations were made in the pre-estuary area, in the mountain-foothill zone, where the river is a typical mountain stream.

Periphyton communities are mainly represented by the northern Alpine and mountainous x, xo, o-saprobic diatom species from the genera Achnanthes, Ceratoneis, Cymbella, Didymosphenia, Diatoma (D.hiemale), Fragilaria, Tabellaria, Synedra (S. amphicephala), Melosira (M.arenaria), Meridion. In the spring, the abundant development of the x-osaprobic golden alga Hydrurus foetidus was noted. In the seasonal aspect is celebrated, as in the river. Boshkyzylsay, a tendency to more noticeable development in the low summer summer-autumn period, the eurybiont o-b-, b-mesosaprobic diatoms of the genera Cocconeis, Cyclotella, Gomphonema, Diatoma, Melosira, Fragilaria, Navicula, Nitzschia, Pinnularia, Surirella; blue-green filamentous and colonial algae from this. Oscillatoriaceae green filamentous, protococcal and desmidic algae from the genera Cosmarium, Closterium, Scenedesmus, Ankistrodesmus, Ulothrix, Spirogyra, Cladophora. Organisms from the group of consuments are singled out mainly in the summer-autumn period.

The bottom communities include mountain and foothill x-o, o-, o-b-, b-mesosaprobic species of spring clans of the genus Amphinemura, mayfly Ameletus alexandrae, Ephemerella submontana, Ecdyonurus rubrofasciatus, Baetis rhodani, B. (Baetis) vardarensis var. caucasicus, Baetis stipposus, Caenis hissari, caddis flies Dinarthrum reductum, Mystrophora altaica, Brachycentrus sp., Hydropsyche ornatula, two-winged genera Dicranota, Dicranomyia, Tipula, beetles of the genus Esolus, Helmis, Stenelmis, manty, and one another, which is attached to the theme, which is attached to the tenets of the Esolus, Helis, Stenelus cubanicus, oligochaete Nais behningi, chironomids of the genera Orthocladius, Pagastia, Eukiefferiella, Tvetenia. The abundance and species diversity of benthofauna is great throughout the year. As well as for Boshkyzylsay river the development of eurybiotic b-a, a-mesosaprobic species is characteristic of Ugam in the summer-autumn period. The values of IS - 1.36-1.74, BPI - 6-9 points, MBI - 6-8 points, the water quality is assessed mainly II and transitional II-III classes; ecological condition - AB (F). [7, p.25]

In the controlled area of the Ugam river, as in other mountain streams with a rapid current and stony-pebbly-sandy bottom, macrophytes did not develop. For Chirchik river with the advancement from the background alignment to the estuarine section, the same tendency remains in changing the complex of abiotic factors and visual indicators as for the Akhangaran river. Downstream increases turbidity, warming of the water mass, overgrowth of the channel by macrophytes, pollution and sedimentation of bottom sediments.

For Chirchik river, depending on the composition of aquatic biocenoses, there are three areas: 1) the upper section (above the city of Gazalkent) is classified as background; 2) a zone of moderate pollution (area from the town of Chirchik to Novomikhailovka village); 3) estuary (city of Chinaz). In the upper background area, the river is characterized by a rapid current, low water temperature, and stony-pebble soils. Water quality is mainly assessed by a transitional class II-III, BPI values - 6-9 points, MBI - 5-6 points, IP - 1.28-1.76; ecological condition - AB. [7, p.26] The species composition and annual variability of the ecological structure of periphyton are in many respects identical to those of the Ugam River. It is possible to note the constant development of x-o-, o-, o-b-mesosaprobic diatom species from 
the genera Achnanthes, Synedra, Cyclotella, Cymbella, Cocconeis, Diatoma (D. hiemale v. Mesodon), Didymosphenia, Fragilaria, Gomphonema (G. intricatum v. pumilum). In the spring-summer period, the development of the x-o-saprobic diatom Ceratoneis arcus and its variations and the mass development of the golden alga Hydrurus foetidus and the red algae Bangia atroporpurea are noted. In the summer-autumn period, diatoms from the genera Amphora, Melosira, Synedra, Gomphonema, Cymatopleura, Navicula, Nitzschia, Rhoicosphenia, Gyrosigma reached a noticeable development; green filamentous algae Spirogyra porticalis, Spirogyra sp., Ulothrix zonata, Ul. tenuissima, Cladophora glomerata, protococcal and desmidium from the genera Scenedesmus, Cosmarium; blue-green algae this. Oscillatoriaceae, etc. Organisms from the group of consuments are singly recorded throughout the entire observation period.

Zoobenthos includes both mountain and foothill o-, ob-, b-mesosaprobic species of mayfly genus Baetis, caddis Apatania childbirth, Brachycentrus, Diptera kind Dicranomyia, water mites of the genus Lebertia, chironomid genera Diamesa, Orthocladius, Pagastia, Tvetenia, and evrisaprobnye plain ba -, a-mesosaprobic species of mayflies of the genus Baetis, caddis of the genera Hydroptila, Hydropsyche, chironomids of the genera Orthocladius, Cricotopus, Rheocricotopus, Eukiefferiella. In the summer-autumn period, a significant increase in the abundance and species diversity of benthic organisms was noted, especially among the Diptera larvae.

In the upper part of the macrophyte associations, a hornpole semi-submerged Ceratophyllum submersum, Myriophyllum spicatum, the ridge Potamogeton pectinatus, and the moss Fontinalis sp. Were observed, which in some months reached mass development.

In the second section (zone of moderate pollution), water quality is rated $\mathrm{W}$ class, the values of BPI and MBI - 5-7 points, IP - 1.55-2.18; ecological condition - AB. [7, p.27]

This site is mainly characterized by a higher trophic level and a good development of aquatic biocenoses throughout the entire observation period, in which both mountain and widespread species of organisms develop. The latter prevail in the summer-autumn period.

This part of the river is characterized by abundant and diverse development of periphyton communities (up to 154 species in the sample), in which, as we move from Chirchik to the village Novomikhaylovka, there is a partial change in the species composition of organisms, namely: the north-alpine and mountain $\mathrm{x}$-o-saprobic species of algae gradually fall downstream, while widespread o-, ob-, b- and ba- Mesosaprobic species from the genera Achnanthes, Amphora, Cymbella, Fragilaria, Diatoma, Melosira, Caloneis, Cyclotella, Cymbella, Cocconeis, Cymatopleura, Bacillaria, Epithemia, Gomphonema, Gyrosigma, Pleurosigma, Navicula, nsh, nom, zomme, Gomphonema, Gyrosigma, Pleurosigma, Niche, Nitma, nom, nom, Gomphonema, Gyrosigma, Nitro. However, along with this, the development of the x-o-saprobic diatom Didymosphenia geminata and spring, mountainfoothill species Denticula tenue, Eunotia arcus was noted in the upper sections of the Chirchik river. At the same time increasing the specific ratio filamentous green and bluegreen algae of the genera Cladophora, Rhizoclonium, Spirogyra, Ulothrix, Oedogonium, Vaucheria, Dactylococcopsis, Microcystis, Merismopedia, Tetrapedia, Gloeocapsa, Gomphosphaeria, Anabaena, Oscillatoria, Lyngbya, Phormidium, Spirulina. In the summerautumn period in the lower sections of this section, especially in the points below the city of Tashkent and to the village. Novomikhovka, noticeably developed green, worms, etc. and decomposers (Sphaerotilus, Pelonema, Bacterium, Beggiatoa). A change in the composition and structure of the periphyton communities indicates an increase in the level of pollution and trophicity of the second section of the river from the town of Chirchik to the village Novomikhaylovka.

Complex benthic organisms advantageously include widespread b-, ba-, a-mesosaprobic types mayflies Baetis genera, Caenis, Trichoptera Hydropsyche genera, Hydroptila, Chironomidae genera Orthocladius, Cricotopus, Eukiefferiella, and dipteran larvae scrapes, 
beetles, bedbugs, dragonfly larvae, mollusks. In the upper ranges, mountain and piedmont o, o-b-mesosaprobic species of daylings are found Ecdyonurus rubrofasciatus, Ephemerella mesoleuca, Baetis vardarensis v. caucasicus, Caenis hissari, diptera of the genus Dicranomyia, chironomids of the genera Diamesa, Orthocladius. Downstream in the zoobenthos, the specific ratio of eurysoprobic species increases, including mollusks, dragonfly larvae, beetles, bugs, oligochaetes, chironomids, which indicates an increase in the trophicity of this area. In the low summer-autumn period, brackish-water species of Cloeon simile, Cricotopus silvestris chironomids, Bidessus beetles, Sigara bugs, etc. also develop. Phytodetritofags, detritofags-collectors, filter creators, and elephant buzzers, and elephant hunters dominated during the year. Shortened food chains, biocenoses work on intensive processing of incoming organic matter.

In the second section, macrophytes developed moderately. In the upper sections, moss Fontinalis sp. The ridge Potamogeton pectinatus, the curle Potamogeton crispus, the ceratus Ceratophyllum demersum, the water fern Azolla caroliniana and the urur Myriophyllum spicatum also noticeably develop downstream with an increase in trophicity during the lowwater summer-autumn period. In the mouth area of the Chirchik river composition of water communities indicates a slight increase in the overall mineralization of water, which is especially noticeable in the summer-autumn period. The level of trophicity also increases here compared to the upper cross-sections. Water quality in terms of periphyton and zoobenthos is estimated mainly by the transitional III-IV class. The values of BPI and MBI 4-5 points, IP - 2.06-2.19, the ecological state of transition - AB-Ab. [7, p.28]

The species composition and structure of the periphyton community as a whole does not have significant differences from the lower alignment (village Novomikhailovka) of the second section of the river. However, during the entire period of observation in the mouth of the Chirchik river more markedly developed b-, ba-, a-mesosaprobic and brackish diatom species from the genera Amphora, Anomoeoneis, Bacillaria, Caloneis, Cocconeis, Coscinodiscus, Cymbella, Diatoma, Diploneis, Fragilaria, Melosira, Gomphonema, Navicula, Nitzschia, Cyclotella, Gyrosigma, Pleurosigma, Cymatopleura, Hantzschia, Rhoicosphenia, Synedra, Surirella, Green Starchy, Cladophora, Spirogyra, Oedogonium, Vaucheria, Hydrodiction, Rhizochesh, Cfr, Cr, Hopz, Oedogonium, Vaucheria, Hydrodiction, Rhizochera, Stylonychia, Rotaria, Chilodonella, Glaucoma, Vorticella, Epistylis, Nematoda).

Figure 2 illustrates how the water quality changes from the source to the mouth of the Chirchik River.

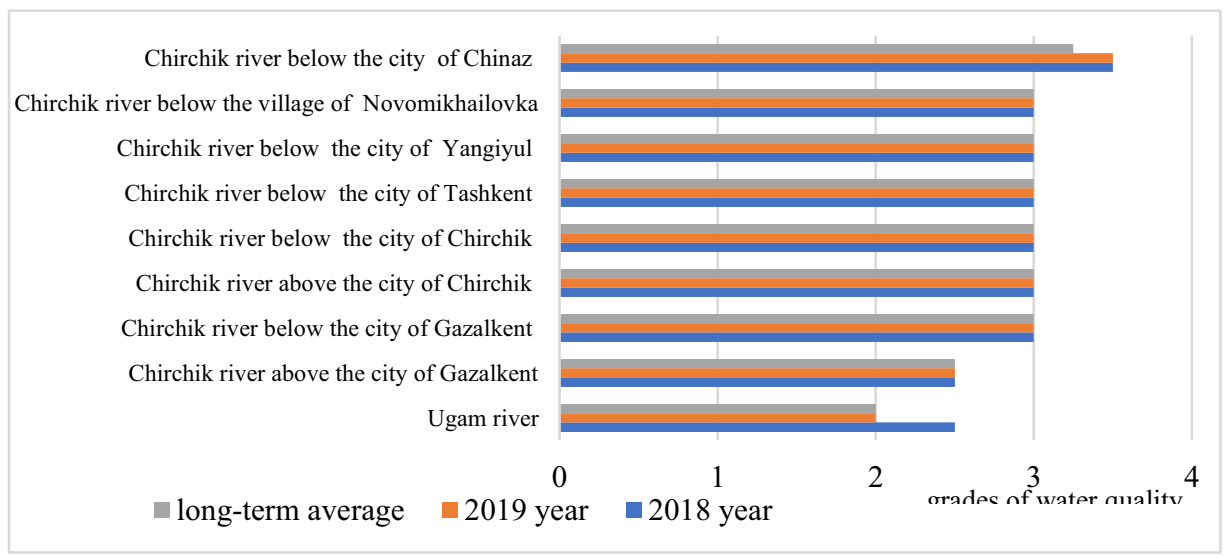

Fig. 2. Dynamics of water quality change in the Basin of Chirchik river 
In the composition of the benthofauna of the mouth area, the specific ratio of a-, a-p-, psaprobic species of organisms increases. In comparison with the lower sections of the second section, a more noticeable development of brackish-water dipteran species, mollusks, beetles, bedbugs, and shrimps is noted here. Among the macrophytes, besides the species characteristic of the second section, throughout the entire survey period, the Azolla caroliniana water fern and Lemna minor cassock developed their highest development during the low-water period, which indicates a high trophic level of the wellhead.

\section{Conclusion}

The obtained hydrobiological information indicates that anthropogenic factors, in particular pollution, cause different changes in depth in the composition, structure and ecological state of aquatic biocenoses. The most biocenoses vary below major sources of pollution and human settlements, in the sections of rivers flowing through agricultural zones, as well as in the estuaries. Stable high / good water quality is typical for background watercourses that are not subject to direct anthropogenic influences, for example, for Boshkyzylsay river on the territory of the reserve, where changes in hydrobiological indicators are of a natural and depend mainly on the dynamics of climatic factors. Formal hydrobiological indices of IP, BPI, MBI do not exceed the limits of perennial fluctuations.

It is necessary to distinguish between the effects on the biota of temperature, hydrological and polluting factors. An increase in water temperature, occurring both under the influence of conditionally clean heated waste waters of the hydroelectric power station and thermal power plants, and natural seasonal heating of the water mass causes activation of biological processes, which leads to an increase in the trophic level of water bodies. Natural temperature successions of aquatic biocenoses are clearly visible in background water bodies, where biocenoses in the cold season qualitatively differ in composition and structure from biocenoses during periods of maximum warming up of these watercourses. The hydrological factor has a significant impact on the development of aquatic biocenoses. In the flood period, a well-known depression of the periphyton and zoobenthos communities is observed, associated with a change in the water level and the demolition of organisms by mechanical action of a sandy-clay suspension. Stabilization of the level regime leads to the clarification of water and stimulates the development of aquatic biota. During this period, the composition of aquatic biocenoses in estuarine areas increases the specific ratio of halophilic species of organisms, indicating an increase in water salinity. Anthropogenic pollution causes changes in the composition and structure of aquatic communities, expressed in the change of dominant complexes of organisms, the simplification of the ecological structure, the appearance of highly saprobic species in the composition of the dominants.

The influence of mineralized collector-drainage waters manifested itself in the lower reaches of the surveyed section of the Syrdarya river within the Tashkent region, as well as in the estuaries of the Chirchik river. In the aquatic biocenoses of these watercourses, along with eurybiotic species of organisms, brackish-water forms also develop. For the pool Chirchik river including its tributaries, the Boshkyzylsay, the Ugam and the Salar and Karasu canals, rivers Boshkyzylsay, Ugam and the upper section of the Chirchik river relating to the zone of formation of flow. For these background watercourses, the average values of the IC are 1.40-1.56, which relates them to the o-saprobic or o-b-mesosaprobic zones. The values of BPI and MBI are high - 6-10 and 5-9 points, which corresponds to grades I-II, II, II-III of water quality. With the advancement to the estuary Chirchik river and an increase in the level of contamination, the average values of IP naturally increase, while BPI and MBI decrease. In the mouth area of the Chirchik river IP reaches 2.11, BPI and MBI are reduced to 4-5 points and reach the "dividing line". 


\section{References}

1. E.H. Bakaeva, A.M. Nikanorov, Hydrobionts in assessing the quality of terrestrial waters ("Science", Moscow, 2006)

2. D.M. Bezmaternykh, L. Yanygina, Environmental, Industrial and Energy Security, 259-263 (2019)

3. Guidance on hydrobiological monitoring of freshwater ecosystems. Ed. V.A. Abakumova, (Gidrometeoizdat, St. Petersburg, 1992)

4. Abdulla R. Kurbanov, Svetlana I. Kim, Zuri A. Mustafaeva, Natalia O. Titova, Scientific works of Dalrybvtuz, 54, 28-43 (2020)

5. A.V. Lyashenko, A.A. Protasov, Hydrobiological Journal, 39(4), 16-25

6. Recommendations. Methods of hydrobiological monitoring of water bodies in the region of Central Asia: RU 52.25.32-97 (Tashkent, 1997)

7. Yearbook of the quality and ecological state of surface waters on hydrobiological indicators in the territory of Uzhydromet's activities for 2019 (Uzgidromet, Tashkent, 2020) 